\title{
VARIASI POLA SIDIK JARI MAHASISWA BERBAGAI SUKU BANGSA DI KOTA MADIUN
}

\author{
Karlina Purbasari, Angga Rahabistara Sumadji \\ Program Studi Biologi, Fakultas MIPA \\ Universitas Katolik Widya Mandala Madiun \\ Emailkpurbasari@yahoo.com, rahabistaraangga@gmail.com
}

Diterima 3 Agustus 2017 disetujui 13 September 2017

\begin{abstract}
The research aimed to find the distribution of fingerprint pattern and the total ridge of students from various ethnis in Madiun. The research was conducted in five Universities in Madiun using Proportional Stratified Random Sampling method. The taking of the fingerprint was conducted by pressing the fingers of each student on the ink pad and the press them on the while paper. The fingerprint patterns were counted by percentage of each pattern and the total ridges of each ethnic were counted by average. The result of the research showed that 10 ethnic had a higher percentage of loop pattern out of 11, they are Javanese $(60,4 \%)$, Dayak $(69 \%)$, Flores (50,59\%), Batakese (56\%), Lampung (90\%), Balinese (70\%), Mentawai (50\%), Banjar $(60 \%)$, Madurese (100\%), and Betawi (70\%). Minang ethnic had a higher whorl pattern than other patterns, that is $70 \%$. The highest average of the total ridge could be found in Batakese 196,33 while the lowest average of the total ridge could be found in Madurese 70. It can be concluded that there was different percentage of each pattern and each total ridge in 11 ethnic.
\end{abstract}

Kata kunci: fingerprint, ethnic, total ridge, Madiun

\section{PENDAHULUAN}

Masyarakat Indonesia adalah sebuah masyarakat yang majemuk. Kemajemukan masyarakat Indonesia terdiri atas keragaman suku bangsa, agama, ras, dan bahasa. Ada kurang lebih 500 suku bangsa yang mendiami seluruh wilayah Indonesia. Suku bangsa adalah golongan manusia yang terikat oleh kesadaran dan identitas akan kesatuan kebudayaan. Pemerintah Indonesia membagi suku bangsa di Indonesia menjadi tiga golongan, yaitu: (1) suku bangsa; (2) golongan keturunan asing; dan (3) masyarakat terasing. Semua suku bangsa memiliki daerah asal dalam wilayah Indonesia, sedangkan golongan keturunan asing tidak memilikinya karena daerah asal mereka terdapat di luar wilayah Indonesia (Cina, Arab, India, Eropa), atau karena keturunan percampuran.
Keragaman suku bangsa ini dapat diidentifikasi dengan jelas berdasarkan segi fisik seperti warna kulit, jenis rambut serta dari segi bahasa yang digunakan (Bachtiar, 1994; Arif, 2013). Karakter lain yang dapat digunakan untuk mempertegas identifikasi suku bangsa adalah pola sidik jari.

Menurut Ramani et. al (2011) sidik jari dapat digunakan secara luas untuk alat identifikasi seseorang, aspek biologis, penurunannya serta perbedaan diantara bangsa-bangsa. Sidik jari terbentuk sejak awal perkembangan embrio yaitu pada umur embrio 13 minggu sampai embrio 24 minggu. Pola sidik jari ditentukan oleh banyak gen (poligen) sehingga secara genetik tidak pernah berubah seumur hidup, kecuali dipengaruhi oleh kerusakan lingkungan (Misbach, 2010). 
Perubahan sidik jari dapat terjadi akibat trauma berat sehingga pola tidak dapat terbentuk kembali (Triwani, 2003). Secara normal, perubahan yang terjadi pada sidik jari adalah pada ukuran sulur yang berlangsung sejalan dengan perkembangan tangan dan kaki (Sikumbang, 1998). Variasi pola sidik jari satu spesies dengan spesies lain berbeda dan umumnya menunjukkan kekhasan masing-masing spesies tersebut. Hal ini dikarenakan sidik jari merupakan pencerminan dari bagian DNA dalam kromosom yang membawa karakter spesifik dari organisme (Surjadi et.al, 1984).

Menurut sistem Galton, pola sidik jari dibedakan menjadi tiga, yaitu bentuk lengkung atau arch, bentuk sosok atau loop, dan lingkaran atau whorl. Pola arch adalah pola dengan garis lengkung sejajar menyerupai busur dan tidak memiliki triradius. Pola loop memiliki bentuk lengkung seperti kait dengan satu triradius. Pola ini ada 2 macam yaitu loop ulna dan loop radial. Pola whorl berbentuk lingkaran dengan sedikitnya memiliki dua triradius, seperti terlihat pada Gambar 1. Frekuensi kehadiran pola sidik jari bervariasi dari satu jari dengan jari yang lain. Frekuensi pola sidik jari loop lebih tinggi dibandingkan bentuk whorl dan arch. Penghitungan banyaknya rigi dilakukan mulai dari triradius sampai ke pusat dari pola sidik jari (Suryo, 2001).

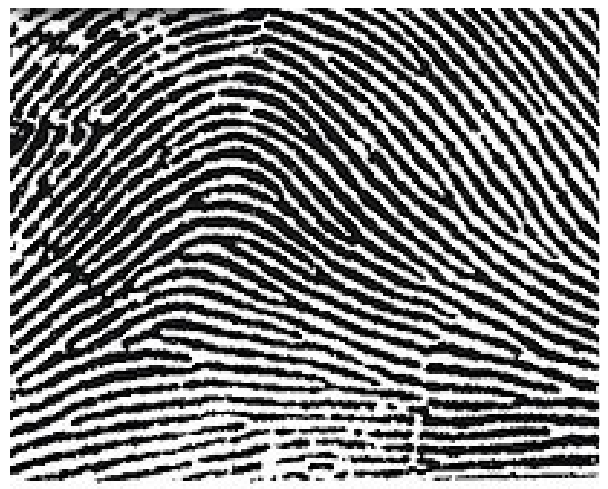

(a)

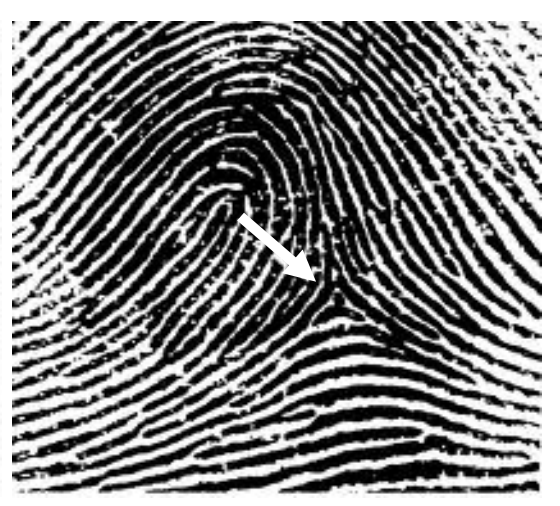

(b)



(c)

Gambar 1. Pola sidik jari manusia. (a) Pola lengkung atau arch, (b) Pola sosok atau loop, (c) Pola lingkaran atau whorl. Tanda panah menunjukkan triradius (Suryo, 2001).

Beberapa penelitian yang menggunakan sidik jari sebagai salah satu alat identifikasi suku bangsa di Indonesia telah dilakukan pada populasi Jawa dan Papua di Surabaya oleh Hidayati (2005). Penelitian serupa juga dilakukan pada suku Dayak Meratus di Kalimantan Selatan oleh Panghiyangani et.al (2006). Mengingat masih banyak keanekaragaman suku bangsa di Indonesia dan mengacu pada penelitian Purbasari dan Sumadji (2017) yang meneliti variasi pola sidik jari suku bangsa di Universitas Katolik Widya Mandala Madiun, maka penelitian ini dilakukan dalam skala yang lebih luas mengingat banyaknya Perguruan Tinggi di Kota Madiun dengan latar belakang mahasiswa berasal dari berbagai pulau di Indonesia. Tujuan penelitian ini adalah untuk melihat variasi pola sidik jari 
mahasiswa dan perbedaan jumlah sulur pada sidik jari mahasiswa berbagai suku bangsa di Kota Madiun. Populasi yang dilibatkan pada penelitian ini adalah populasi mahasiswa pada lima Perguruan Tinggi di Kota Madiun.

\section{METODE}

Penelitian dan pengambilan sampel dilakukan di lima Perguruan Tinggi di Kota Madiun, yaitu Universitas Merdeka Madiun, Universitas PGRI Madiun, Politeknik Negeri Madiun, STIKES Bhakti Husada Mulia Madiun dan Sekolah Tinggi Widya Yuwana Madiun. Metode pengambilan sidik jari mahasiswa dan penentuan jumlah sampel mengacu pada penelitian Purbasari dan Sumadji (2017). Penelitian menggunakan metode acak berstrata (Proportional Stratified Random Sampling). Sampel yang digunakan adalah mahasiswa dengan berbagai suku bangsa, berasal dari keturunan asli suku tersebut dan tidak ada percampuran antar suku dalam keluarganya. Penentuan jumlah sampel pada tiap suku bangsa adalah sebagai berikut:

1. Apabila jumlah mahasiswa dalam satu suku bangsa adalah 1 - 10 mahasiswa, maka semua mahasiswa tersebut digunakan sebagai sampel.

2. Apabila jumlah mahasiswa dalam satu suku bangsa $>10$, maka mahasiswa yang digunakan sebagai sampel sebanyak 10 mahasiswa yang diambil secara acak.

Sidik jari tangan mahasiswa diambil pada selembar kertas yang sudah disediakan. Sebelum pengambilan sidik jari, tangan mahasiswa dibersihkan dengan alkohol terlebih dahulu dan dikeringkan. Masing-masing ujung jari diletakkan pada bantalan stempel yang telah diberi tinta kemudian digulingkan pada kertas putih, dimulai dari ibu jari tangan kanan sampai jari kelingking dan ibu jari tangan kiri sampai jari kelingking.

Hasil pengambilan sidik jari diamati polanya dan dihitung jumlah sulurnya. Jumlah sulur dihitung dengan menentukan triradius terlebih dahulu, kemudian ditarik garis dari triradius sampai ke pusat pola. Jumlah sulur yang dilewati sepanjang garis dihitung sebagai jumlah sulur masing-masing jari. Pada pola whorl yang mempunyai dua triradius, hasil perhitungan yang diambil adalah hasil perhitungan dengan sulur terbanyak.

Hasil sidik jari mahasiswa berbagai suku bangsa yang diperoleh disusun dalam tabel dan ditabulasi. Perhitungan persentase masing-masing pola sidik jari dilakukan pada masing-masing suku bangsa dengan rumus berikut:

$$
\begin{aligned}
& \% \cdot \text { loop } .=\frac{\text { jumlah } \cdot \text { keseluruhan } \cdot \text { loop }}{\text { jumlah } \cdot \text { keseluruhan } \cdot \text { sidik } \cdot \text { jari }} \times \cdot 100 \% \\
& \% \cdot \text { arch }=\frac{\text { jumlah } \cdot \text { keseluruhan } \cdot \text { arch }}{\text { jumlah } \cdot \text { keseluruhan } \cdot \text { sidik } \cdot \text { jari }} \times 100 \% \\
& \% \cdot \text { whorl }=\frac{\text { jumlah } \cdot \text { keseluruhan } \cdot \text { whorl }}{\text { jumlah } \cdot \text { keseluruhan } \cdot \text { sidik } \cdot \text { jari }} \times \cdot 100 \%
\end{aligned}
$$

Jumlah sulur masing-masing jari tiap individu dijumlahkan untuk mendapatkan jumlah total sulur (Total Ridge Count/ $T R C$ ). Kemudian dihitung rata-rata jumlah total sulur pada tiap-tiap suku bangsa dan dilakukan analisis secara deskriptif.

\section{HASIL DAN PEMBAHASAN}

Penelitian ini menggunakan 92 mahasiswa dari sebelas suku bangsa yang ditemukan, yaitu 50 mahasiswa suku Jawa, 10 mahasiswa suku Dayak, 17 mahasiswa suku Flores, 5 mahasiswa suku Batak, 1 mahasiswa suku Lampung, 1 mahasiswa suku Bali, 3 mahasiswa suku Mentawai, 1 mahasiswa suku Banjar, 1 mahasiswa suku Madura, 1 mahasiswa suku Betawi, dan 2 mahasiswa suku Minang. Persentase sidik jari tiap-tiap suku bangsa disajikan dalam Tabel 1. 
Tabel 1. Persentase Pola Sidik Jari Whorl, Loop dan Arch pada Berbagai Suku Bangsa

\begin{tabular}{clccc}
\hline No & Suku & $\begin{array}{c}\% \\
\text { Whorl }\end{array}$ & $\begin{array}{c}\% \\
\text { Loop }\end{array}$ & $\begin{array}{c}\text { \% } \\
\text { Arch }\end{array}$ \\
\hline 1 & Jawa & 37.6 & 60.4 & 2 \\
2 & Dayak & 30 & 69 & 1 \\
3 & Flores & 48.24 & 50.59 & 1.17 \\
4 & Batak & 36 & 56 & 8 \\
5 & Lampung & 0 & 90 & 10 \\
6 & Bali & 30 & 70 & 0 \\
7 & Mentawai & 33.33 & 50 & 16.67 \\
8 & Banjar & 40 & 60 & 0 \\
9 & Madura & 0 & 100 & 0 \\
10 & Betawi & 20 & 70 & 10 \\
11 & Minang & 70 & 30 & 0 \\
\hline
\end{tabular}

Tabel 1 memperlihatkan bahwa dari sebelas suku bangsa yang ditemukan, terdapat persamaan pada sepuluh suku bangsa diantaranya yaitu memiliki persentase loop paling tinggi, disusul whorl, kemudian arch. Hanya suku Minang yang memiliki persentase whorl lebih tinggi dibanding dua pola lain yaitu loop dan arch. Pada sepuluh suku bangsa yang didominasi pola loop, terdapat perbedaan persentase masing-masing pola untuk tiap-tiap suku bangsa. Pada suku Madura $100 \%$ pola loop, artinya bahwa pada sampel suku Madura hanya dijumpai pola loop saja, tidak dijumpai pola lain. Suku Lampung mempunyai persentase loop sebesar 90\%, suku Bali dan Betawi mempunyai persentase loop yang sama yaitu 70\%. Suku Dayak mempunyai persentase loop 69\%, suku Jawa 60,4\%, suku Banjar 60\%, suku Batak 56\%, suku Flores 50,59\%, dan suku Mentawai 50\%. Sedangkan untuk suku Minang didominasi oleh pola whorl sebesar $70 \%$.

Hasil penelitian ini dapat digunakan untuk menentukan variasi pola sidik jari berbagai suku bangsa yang tercermin dari persentase masing-masing pola pada tiaptiap suku bangsa. Persentase kemunculan pola sidik jari suku Jawa pada penelitian ini sejalan dengan hasil penelitian pola sidik jari suku Jawa dan Papua di Surabaya oleh Hidayati (2015), suku Jawa didominasi oleh pola loop $(52,1 \%)$, kemudian whorl (41,6\%) dan arch (6,3\%) akan tetapi besarnya persentase masing-masing pola tidak sama.

Penelitian lain yang juga sejalan dengan penelitian ini adalah penelitian sidik jari pada suku Dayak Meratus oleh Panghiyangani, dkk (2006). Suku Dayak didominasi oleh pola loop ulnar $(67,07 \%)$, whorl $(25,54 \%)$, arch $(4,62 \%)$ dan loop radial $(2,77 \%)$. Pola loop dibagi menjadi dua macam pola yaitu loop ulna dan loop radial, sedangkan pola whorl dibagi menjadi empat macam pola yaitu plain whorl, centralpocket loop, double loop, dan accidental whorl. Berdasarkan pembagian ini, hasil penelitian Panghiyangani, dkk (2006) diperoleh persentase tertinggi suku jawa adalah pola loop yang terdiri dari loop ulnar dan loop radial.

Hasil penelitian ini apabila dipisahkan berdasarkan jenis kelamin, maka diperoleh hasil seperti disajikan dalam tabel 2. Suku Jawa, Dayak, Lampung, Bali, Banjar, Madura dan Betawi pada individu laki-laki maupun perempuan diperoleh hasil yang sama yaitu persentase tertinggi dijumpai pada pola loop, kemudian whorl dan yang terkecil adalah arch.

Hal ini juga dijumpai pada suku Flores, Batak, dan Mentawai individu perempuan. Sedangkan pada individu lakilaki suku Flores, Batak, dan Mentawai, persentase tertinggi adalah pola whorl, diikuti loop kemudian arch. Untuk semua suku yang diperoleh pada penelitian ini menunjukkan bahwa pola arch memiliki persentase terkecil. Menurut Suryo (2001), frekuensi pola sidik jari arch adalah kirakira sebesar 5\%, frekuensi ini paling kecil daripada pola loop dan whorl.

Menurut Hall (1989) pola loop ulnar merupakan pola dasar sidik jari manusia, namun ada beberapa gen yang berperan dalam pembentukan sidik jari 
sehingga polanya mengalami banyak variasi. Pola sidik jari ditentukan sangat kuat oleh faktor genetik, tetapi dalam periode pembentukannya juga dipengaruhi oleh keadaan lingkungan. Gangguan proliferasi sel epitel dermis, tekanan pada kulit, gangguan pembuluh darah perifer, kekurangan pasokan oksigen, dan gangguan proses keratinisasi saat pertumbuhan embrio dapat mempengaruhi variasi pola sidik jari terutama bila terjadi pada kehamilan 19 minggu (Babler, 1979). Selain itu faktor lingkungan yang juga berpengaruh antara lain diet dan asupan kimiawi ibu, kadar hormon, dan tingkat radiasi tingkat (Wertheim dan Maceo, 2002).

Rata-rata jumlah total sulur sidik jari disajikan pada tabel 3. Berdasarkan tabel diperoleh suku Batak mempunyai jumlah total tertinggi $(196,33)$, kemudian suku Minang (160), suku Flores (128,71), suku Banjar (128), suku Bali (122), suku Jawa (111,36), suku Dayak (104,3), suku Mentawai (89), suku Betawi (78), suku Lampung (73), dan suku Madura (70). Apabila dipisahkan berdasarkan jenis kelamin diperoleh hasil bahwa jumlah total sulur pada individu laki-laki lebih tinggi dibanding jumlah sulur pada individu perempuan. Hasil ini sesuai dengan penelitian yang telah dilakukan oleh Sufitni (2007), jumlah sulur baik pada kelompok normal maupun kelompok retardasi mental lebih tinggi pada individu laki-laki daripada perempuan. Hasil ini juga sesuai dengan penelitian Suryadi (1993) yang melakukan penelitian pada mahasiswa Fakultas Kedokteran di Universitas Indonesia, yang menunjukkan bahwa jumlah total sulur laki-laki lebih banyak daripada perempuan.

Tabel 2. Persentase Sidik Jari Berbagai Suku berdasarkan Jenis Kelamin

\begin{tabular}{|c|c|c|c|c|c|}
\hline No & Suku & Jenis Kelamin & \% Whorl & \% Loop & $\%$ Arch \\
\hline \multirow[t]{2}{*}{1} & Jawa & $\mathrm{L}$ & 40.69 & 58.96 & 0.34 \\
\hline & & $\mathrm{P}$ & 33.33 & 62.38 & 4.29 \\
\hline \multirow[t]{2}{*}{2} & Dayak & $\mathrm{L}$ & 30 & 70 & - \\
\hline & & $\mathrm{P}$ & 30 & 68.57 & 1.43 \\
\hline \multirow[t]{2}{*}{3} & Flores & $\mathrm{L}$ & 60 & 36.67 & 3.33 \\
\hline & & $\mathrm{P}$ & 41.82 & 58.18 & - \\
\hline \multirow[t]{2}{*}{4} & Batak & $\mathrm{L}$ & 60 & 40 & - \\
\hline & & $\mathrm{P}$ & - & 80 & 20 \\
\hline \multirow[t]{2}{*}{5} & Lampung & $\mathrm{L}$ & & & \\
\hline & & $\mathrm{P}$ & - & 90 & 10 \\
\hline \multirow[t]{2}{*}{6} & Bali & $\mathrm{L}$ & 30 & 70 & 0 \\
\hline & & $\mathrm{P}$ & & & \\
\hline \multirow[t]{2}{*}{7} & Mentawai & $\mathrm{L}$ & 45 & 40 & 15 \\
\hline & & $\mathrm{P}$ & 10 & 70 & 20 \\
\hline \multirow[t]{2}{*}{8} & Banjar & $\mathrm{L}$ & 40 & 60 & 0 \\
\hline & & $\mathrm{P}$ & & & \\
\hline \multirow[t]{2}{*}{9} & Madura & $\mathrm{L}$ & 0 & 100 & 0 \\
\hline & & $\mathrm{P}$ & & & \\
\hline \multirow[t]{2}{*}{10} & Betawi & $\mathrm{L}$ & & & \\
\hline & & $\mathrm{P}$ & 20 & 70 & 10 \\
\hline \multirow[t]{2}{*}{11} & Minang & $\mathrm{L}$ & 70 & 30 & 0 \\
\hline & & $\mathrm{P}$ & 70 & 30 & 0 \\
\hline
\end{tabular}


Variasi Pola Sidik Jari Mahasiswa Berbagai Suku Bangsa di Kota Madiun

Tabel 3. Jumlah Sulur Sidik Jari pada Berbagai Suku Bangsa

\begin{tabular}{lccc}
\hline \multirow{2}{*}{ Suku bangsa } & \multicolumn{2}{c}{ Jumlah sulur } & Rata-rata jumlah \\
\cline { 2 - 3 } sulur
\end{tabular}

Pola sidik jari dan jumlah sulur pada sidik jari dipengaruhi oleh banyak hal, akan tetapi yang diduga berperan utama dalam pembentukannya adalah sel saraf di lapisan epidermis (Matthew, 2003). Perkembangan sulur pada waktu kehamilan dibedakan atas dua tahap, yaitu tahap pembentukan sulur primer dan tahap pembentukan sulur skunder. Tahap pembentukan sulur primer terjadi sekitar minggu ke 10 sampai minggu ke 17 setelah fertilisasi, sedangkan tahap pembentukan sulur skunder terjadi pada minggu ke 18 sampai minggu ke 25 (Babler, 1979). Sulur atau guratan pada jari ini dapat meningkatkan gesekan, memperbaiki sentuhan, membantu tangan untuk mengenali benda-benda di sekitar dengan menghilangkan tekstur permukaan (Jain, et al. 2010).

Pada pewarisan pola sidik jari, alam telah menetapkan pola pewarisannya (tabel 4), faktor genetik mengatur kapan dan dimana pola sidik jari akan terbentuk. Sedangkan untuk pembentukan sulur, banyaknya sulur yang terbentuk langsung dipengaruhi oleh gen sehingga gen yang terlibat lebih banyak dibandingkan pada saat pembentukan pola sidik jari. Meskipun pola sidik jari dan jumlah sulur diwariskan secara genetik, akan tetapi jumlah sulur lebih dapat diwariskan daripada pola sidik jari (Wertheim dan Maceo, 2002).

Tabel 4. Pewarisan Pola Sidik Jari

\begin{tabular}{|c|c|c|c|}
\hline Jari & Pola Pewarisan & Genotipe & Fenotipe \\
\hline Ibu jari & Semidominan & $\begin{array}{l}\text { AA } \\
\text { Aa } \\
\text { aa }\end{array}$ & $\begin{array}{l}\text { Whorl, kedua ibu jari, } 2 \text { loop ulnar, atau } 1 \text { loop ulnar } \\
\text { dan } 1 \text { whorl }\end{array}$ \\
\hline Ibu jari & Dominan & B- & Arch pada ibu jari dan jari lainnya \\
\hline $\begin{array}{l}\text { Jari } \\
\text { telunjuk }\end{array}$ & Semidominan & $\mathrm{C}-$ & $\begin{array}{l}\text { Loop radial pada jari telunjuk, pola arch pada jari } \\
\text { tengah }\end{array}$ \\
\hline & & $\mathrm{Cc}$ & \\
\hline $\begin{array}{l}\text { Jari } \\
\text { kelingking }\end{array}$ & Resesif & dd & Loop radial \\
\hline Semua jari & Dominan & $\mathrm{E}$ & $\begin{array}{l}\text { Whorl pada semua jari kecuali jari tengah pola loop } \\
\text { ulnar }\end{array}$ \\
\hline Semua jari & Dominan & F- & Arch pada jari \\
\hline
\end{tabular}

Sumber: Wertheim dan Maceo, 2002 
Purbasari, dkk

\section{SIMPULAN}

Pada penelitian ini ditemukan sebelas suku bangsa, sepuluh suku bangsa memiliki persentase pola loop lebih tinggi dibanding pola lain yaitu pada suku Jawa $(60,4 \%)$, Dayak (69\%), Flores (50,59\%), Batak (56\%), Lampung (90\%), Bali (70\%), Mentawai (50\%), Banjar (60\%), Madura (100\%), dan Betawi (70\%). Pada suku Minang mempunyai persentase pola whorl lebih tinggi dibanding pola lain yaitu sebesar 70\%. Rata-rata jumlah sulur sidik jari tertinggi dijumpai pada suku Batak (196,33), sedangkan rata-rata jumlah sulur sidik jari terendah dijumpai pada suku Madura (70). Jumlah sulur laki-laki lebih tinggi dibandingkan jumlah sulur perempuan pada semua suku bangsa.

\section{DAFTAR PUSTAKA}

Arif, D.B. (2013). Membingkai Keberagaman Indonesia: Perspektif Pendidikan Kewarganegaraan Program Kurikuler. Penguatan Kompetensi Calon Praktikan PPL Program Studi PPKN. Universitas Ahmad Dahlan Yogyakarta.

Babler, (1979). Quantitative differences in Morphogenesis of Human Epidermalring desbirth Defect. Original Jurnal series, 15: 199-208.

Bachtiar, H. (1994). Masyarakat Indonesia. Majalah Ilmu-ilmu Sosial Di Indonesia. Jilid xx (4).

Hall, J.G., G.F.I. Ursula, and J.E. Allanson. (1989). Handbook of Normal Physical. Oxford University Press, New York, Toronto

Hidayati, F. (2015). Variasi Pola Sidik Jari pada Populasi Jawa dan Papua. AntroUnairdotNet. 4(1): 30-41.

Jain, A.K., Feng, J., Nandakumar, K. 2010. Fingerprint Matching. Published by the IEEE Computer Society. http:// ComputingNow.computer.org.

Matthew TA, Jay S, Leanne EV, Teresa
AB, and Qurwant KT. (2003). Neuro Developmental Interaction Sconferring Risk for Schizophrenia: A Study of Dermatoglyphic Markers in Patients and Relatives. Schizophrenia Bulletin. 29(3):595605.

Misbach, I. H. (2010). Dahsyatnya Sidik Jari: Menguak Bakat dan Potensi untuk Merancang Masa Depan Melalui Fingerprint Anallisys. Jakarta : Visi Media.

Panghiyangani R, Rosida L, Kartika Y. (2006). Gambaran Sidik Jari Tangan Suku Dayak Meratus Di Desa Haruyan Kecamatan Hantakan Kalimantan Selatan. Proceding Pertemuan Ilmiah Nasional PAAIYogyakarta.

Purbasari, K., dan Sumadji, A.R. (2017). Variasi Pola Sidik Jari Mahasiswa Berbagai Suku Bangsa di Universitas Katolik Widya Mandala Madiun. Seminar Nasional Biologi "SIIMBIOSIS 2" Universitas PGRI Madiun.

Ramani, P., Abhilash, H. J. Sherlin, Anuja, P. Premkuman, Chandrasekar, Sentamilselvi, Janaki. (2011). Conventional Dermatoglyphics Revived Concept: A Review. International Journal of Pharma and Bio Science. 2 (3).

Sikumbang, D. (1998). Dermatoglifi tangan pada pengemban Thalassemia. Jurnal Sains dan Teknologi. 4(1).

Sufitni. (2007). Pola Sidik Jari pada Kelompok Retardasi Mental dan Kelompok Normal. Majalah Kedokteran Nusantara. 40 (3): 180190.

Surjadi, R., Satmjoko, R., Rafiah, R.S., Syahrum, M.H., Ramelan, W. (1984). Pola Sidik Jari dan Total Ridge Count Kelompok Residivis di Indonesia. Majalah Kedokteran Indonesia. 34 (3): 101-104.

Suryadi R. (1993). Pola Sidik Jari dan 
Variasi Pola Sidik Jari Mahasiswa Berbagai Suku Bangsa di Kota Madiun

Jumlah Jalur Total Mahasiswa Fakultas Kedokteran Universitas Indonesia. 343(12): 751-754.

Suryo. (2001). Genetika Manusia. Yogyakarta: Universitas Gadjah Mada Press.

Triwani.(2003). Pemeriksaan Dermatoglifi sebagai Alat Identifikasi dan
Diagnostik. Jurnal Kesehatan \& Kedokteran Universitas Sriwijaya. (2): 2861-2866.

Wertheim, K and A, Maceo. 2002. The Critical Stage of Friction Ridge and Pattern Formation. Journal of Forensic Identification. 52 (1): 3585. 